\section{PENGENALAN UNIT \\ PENANGGULANGAN KEADAAN \\ DARURAT DI BANDARA BAGI \\ SISWA SMK PENERBANGAN DI \\ WILAYAH LAMPUNG DAN SIDOARJO}

Nawang Kalbuana ${ }^{\text {** }}$, Oke Hendra ${ }^{2}$, Pangsa Rizkina

Aswia ${ }^{3}$, Dwi Lestary ${ }^{4}$, Kardi ${ }^{5}$, Solihin ${ }^{6}$

1,2,3,4,5,6) Politeknik Penerbangan Indonesia Curug

* Nawang Kalbuana

Email : nawang.kalbuana@ppicurug.ac.id

\begin{abstract}
PKP-PK unit is an emergency response unit at the airport whose location is within the air-side area that not everyone can enter. The community around the airport and many vocational aviation students have not received comprehensive information related to this PKP-PK Unit. This Unit has a vital role, especially at the time of the accident at the airport. Community Service Activities (PKM) is one of the activities of Tridharma Higher Education that the academic community must carry out at the Polytechnic of Aviation Indonesia Curug. Because it is still in the pandemic condition, Covid-19 PKM activity is done through Webinar with Zoom. This webinar activity was attended by Vocational Aviation Students in Lampung and Sidoarjo regions in collaboration with Karang Taruna Sedati Gede Sidoarjo village, East Java. After this activity is completed, it is expected that it will increase the knowledge and insight of the students of SmK Flight regarding emergency management units at the airport.

Keywords: PKP-PK Unit; Aviation Vocational High School; Airport; Covid-19 pandemic
\end{abstract}

\begin{abstract}
Abstrak
Unit PKP-PK merupakan unit penanggulangan keadaan darurat di bandar udara yang lokasinya berada dalam wilayah sisi udara (airside) yang tidak semua orang dapat memasukinya sehingga masyarakat sekitar bandara maupun siswa SMK Penerbangan banyak yang belum mendapatkan informasi komprehensif terkait Unit PKP-PK ini. Unit ini memiliki peran yang sangat vital khususnya pada saat terjadi peristiwa kecelakaan di bandara. Kegiatan Pengabdian Kepada Masyarakat (PKM) merupakan salah satu kegiatan Tridharma Perguruan Tinggi yang wajib dilaksanakan oleh civitas akademika di Politeknik Penerbangan Indonesia Curug. Dikarenakan masih dalam kondisi Pandemik Covid-19 kegiatan PKM ini dilakukan melalui Webinar dengan Zoom. Kegiatan webinar ini diikuti oleh Siswa SMK Penerbangan di wilayah Lampung dan Sidoarjo dengan bekerjasama dengan Karang Taruna Desa Sedati Gede Sidoarjo, Jawa Timur. Diharapkan setelah kegiatan ini selesai mampu menambah pengetahuan dan wawasan para siswa SMK Penerbangan mengenai unit penanggulangan keadaan darurat di Bandara.
\end{abstract}

Kata Kunci: Unit PKP-PK; SMK Penerbangan; Bandara; Pandemik Covid-19 
Pengenalan Unit Penanggulangan Keadaan Darurat di Bandara bagi Siswa SMK Penerbangan di Wilayah Lampung dan Sidoarjo

Nawang Kalbuana, Oke Hendra, Pangsa Rizkina Aswia, Dwi Lestary, Kardi' Solihin

Volume 1, No. 3, Desember 2021 hal. 232-239

DOI Artikel: 10.46306/jub.v1i3.44

\section{PENDAHULUAN}

Bandara memiliki unit yang berperan sangat penting pada keadaan emergency yaitu Unit Pertolongan Kecelakaan Penerbangan - Pemadam Kebakaran (PKP-PK) (Presiden Republik Indonesia, 2009, Kementerian Perhubungan Republik Indonesia, 20I5). Menurut (Pamuraharjo, 2020; Vinod, 202I) Unit PKP-PK bertugas untuk menanggulangi keadaan darurat di Bandara (Direktorat Jenderal Perhubungan Udara, 2015, 2016; Kementerian Perhubungan Republik Indonesia, 2015; Menteri Perhubungan Republik Indonesia, 2015), menyelamatkan manusia dan barang dari pesawat yang mengalami kecelakaan atau kebakaran baik ketika lepas landas atau tinggal landas, memadamkan, mengendalikan, menyelamatkan manusia dan barang dari peristiwa kebakaran. Pentingnya posisi Unit PKP-PK di Bandara ini sayangnya tidak diiringi dengan sosialisasi yang luas kepada masyarakat umum ataupun pelajar di SMK Penerbangan sehingga banyak dari masyarakat tidak mengetahui keberadaan dari Unit PKP-PK di bandara.

Kondisi pandemi Covid 19 (Arnas, Y; Lamtiar, S; Kurniawati, Z; Kurnianto, B; Kalbuana, 202I; Hastomo, Karno, Kalbuana, Nisfiani, \& ETP, 202I; Hendriarto, Mursidi, Kalbuana, Aini, \& Aslan, 202I; Nurwati, Prastio, \& Kalbuana, 202I; Prasetyo, B; Utami, S; Abdusshomad, A; Wijaya, M; Kalbuana, 202I; Yohana; Kalbuana, N; Solihin; Yanti, 2020) dan juga kebijakan PPKM yang dicanangkan pemerintah (Devi, Devi, Warasniasih, Masdiantini, \& Musmini, 2020; Olivia, Gibson, \& Nasrudin, 2020; Sparrow, Dartanto, \& Hartwig, 2020; Today, 2021) menyebabkan kendala bagi PKM untuk mengumpulkan peserta penyuluhan ini. Sehingga dengan keterbatasan ini diperlukan pemaksimalan teknologi informasi agar kegiatan PKM tetap dapat dilaksanakan. Kegiatan melalui webinar ini dilakukan secara virtual menggunakan aplikasi Zoom Meeting sehingga bisa mengurangi kegiatan yang mengumpulkan orang banyak yang merupakan media penyebaran virus Covid 19 (Kalbuana \& Kurnianto, 20II; Kalbuana et al., 2020, 202I; Pattiapon et al., 2021; Prasetyo, Rohman, Solihin, Sundoro, \& Kalbuana, 202 I; Sihono et al., 202I). Selain itu juga, melalui webinar, jangkauan peserta bisa lebih luas karena peserta dapat berasal dari mana saja selama mereka memiliki koneksi internet.

Politeknik Penerbangan Indonesia Curug (PPI Curug) yang merupakan salah satu lembaga pendidikan vokasi di Indonesia di bawah Kementerian Perhubungan turut berperan aktif dalam menekan laju penyebaran virus covid 19 dengan mematuhi protocol kesehatan dalam melaksanakan kebiasaan normal baru (new normal) oleh seluruh civitas akademika. Tidak hanya berhenti di situ saja, melalui kegiatan Pengabdian Kepada Masyarakat (PKM) sebagai salah satu Tridharma Perguruan Tinggi, dosen dan Taruna PPI Curug ikut andil dalam memberikan pemahaman dan wawasan terkait unit penanggulangan keadaaan darurat di bandara meskipun dengan segala keterbatasan yang disebabkan oleh pandemi Covid 19 yang sedang terjadi tidak hanya di Indonesia tetapi juga di dunia. 
Pengenalan Unit Penanggulangan Keadaan Darurat di Bandara bagi Siswa SMK Penerbangan di Wilayah Lampung dan Sidoarjo

Nawang Kalbuana, Oke Hendra, Pangsa Rizkina Aswia, Dwi Lestary, Kardi' Solihin

Volume 1, No. 3, Desember 2021 hal. 232-239

DOI Artikel: 10.46306/jub.v1i3.44

\section{METODE PENGABDIAN}

Kegiatan Pengabdian Kepada Masyarakat (PKM) dosen PPI Curug dilaksanakan dalam bentuk Webinar pengenalan Unit PKP-PK bagi siswa SMK Penerbangan di Lampung dan Sidoarjo melalui zoom meeting dengan alamat meeting (ID meeting dan password) akan disampaikan melalui aplikasi grup sosial media. Dalam pelaksanaan kegiatan PKM ini akan dilakukan monitoring dan evaluasi (Monev) oleh tim reviewer dan atau perwakilan dari Pusat Penelitian dan Pengabdian Kepada Masyarakat (Pusat PPM) Politeknik Penerbangan Indonesia Curug (PPI Curug). Penjelasan diberikan dalam bentuk teks dan gambar serta video sehingga mudah dipahami. Setelah kegiatan sosialisasi berakhir diharapkan siswa-siswa SMK Penerbangan memiliki pandangan yang komprehensif tentang unit PKP-PK dibandara. Pengetahuan dasar yang diberikan selama kegiatan Pengabdian Kepada masyarakat adalah sebagai berikut:

Materi I: Pengetahuan Dasar tentang Bandar Udara (Bandara)

Materi 2: Pengenalan Unit Penanggulangan Keadaan Darurat

Materi 3: Profesi Petugas/Unit PKP-PK di Bandara

Materi 4: Kendaraan Utama dan Kendaraan Pendukung Unit PKP-PK di Bandara

Materi 5: Gedung Fire Station

\section{PELAKSANAAN DAN PEMBAHASAN}

\section{Permasalahan Mitra}

Permasalahan yang dihadapi mitra adalah minimnya informasi terkait unit penanggulangan keadaan darurat di bandara pada lingkungan mitra. Namun kondisi pandemi Covid 19 memberikan keterbatasan dalam pemberian seminar secara luring (Mayanty, Rusmana, \& Nurrahman, 202I), sehingga kegiatan PKM ini dilakukan secara daring kepada para siswa SMK Penerbangan diwilayah Lampung dan Sidoarjo Jawa Timur dalam bentuk webinar melalui media zoom meeting.

\section{Solusi Yang Ditawarkan}

Berdasarkan uraian analisa situasi dan kondisi permasalahan mitra di atas, dosen PPI Curug dan bersama taruna program studi PKP Angkatan 14 dan 15 menawarkan solusi melalui kegiatan Pengabdian Kepada Masyarakat (PKM) dalam bentuk kegiatan webinar Pengenalan Unit Penanggulangan Keadaan Darurat di Bandara bagi Siswa SMK di Lampung dan Sidoarjo bekerjasama dengan Karang Taruna Desa Sedati Gede Sidoarjo, Jawa Timur guna penambahan pengetahuan dan wawasan mengenai Unit PKP-PK di kalangan generasi muda dan menargetkan peserta sebanyak 146 orang siswa SMK Penerbangan.

Permasalahan terkait pemahaman bisa diselesaikan dengan pendidikan. Ada beragam jenis kegiatan pendidikan yang bisa dilakukan untuk meningkatkan pemahaman masyarakat seperti kursus, sosialisasi, pendidikan formal, dan pelatihan. Menyikapi kondisi pandemi Covid 19, solusi yang paling mungkin dilakukan adalah dengan melakukan kegiatan seminar atau kursus singkat yang memanfaatkan teknologi 
Pengenalan Unit Penanggulangan Keadaan Darurat di Bandara bagi Siswa SMK Penerbangan di Wilayah Lampung dan Sidoarjo

Nawang Kalbuana, Oke Hendra, Pangsa Rizkina Aswia, Dwi Lestary, Kardi Solihin

Volume 1, No. 3, Desember 2021 hal. 232-239

DOI Artikel: 10.46306/jub.v1i3.44

informasi. Bentuk yang paling sering digunakan adalah menggunakan media virtual seperti Zoom Meeting.

Berikut dokumentasi kegiatan Pengabdian kepada masyarakat "Webinar Pengenalan Unit

\section{Penanggulangan Keadaan Darurat Di Bandara Bagi Siswa SMK Penerbangan Di Wilayah}

Lampung Dan Sidoarjo” yang dilakukan secara online:

a. Rapat persiapan kegiatan Webinar dengan karang taruna dan Kepada Desa Sedati Gede Sidoarjo, Jawa Timur
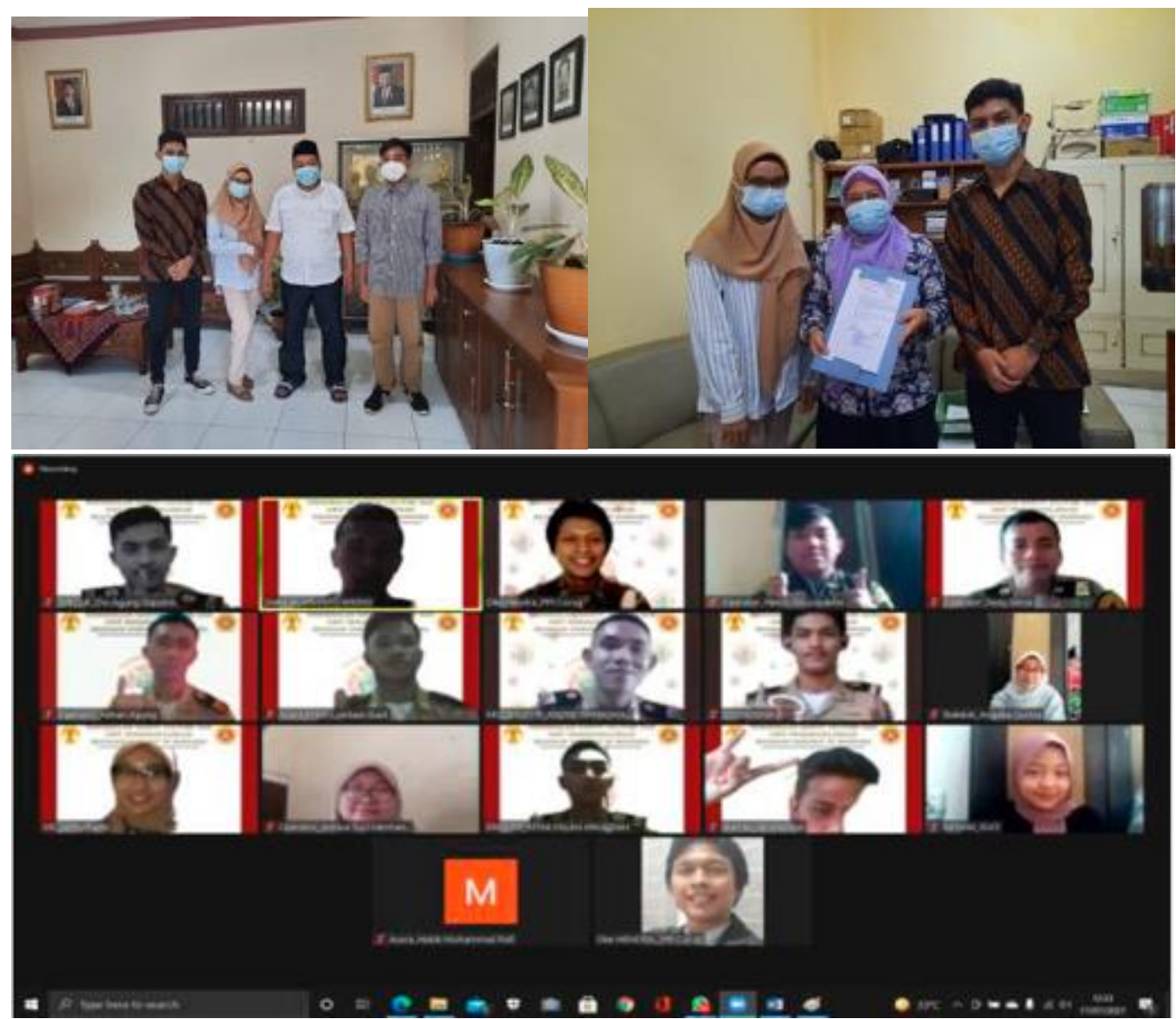
Pengenalan Unit Penanggulangan Keadaan Darurat di Bandara bagi Siswa SMK Penerbangan di Wilayah Lampung dan Sidoarjo

Nawang Kalbuana, Oke Hendra, Pangsa Rizkina Aswia, Dwi Lestary, Kardi' Solihin

Volume 1, No. 3, Desember 2021 hal. 232-239

DOI Artikel: 10.46306/jub.v1i3.44

b. Pelaksanaan kegiatan PKM Online
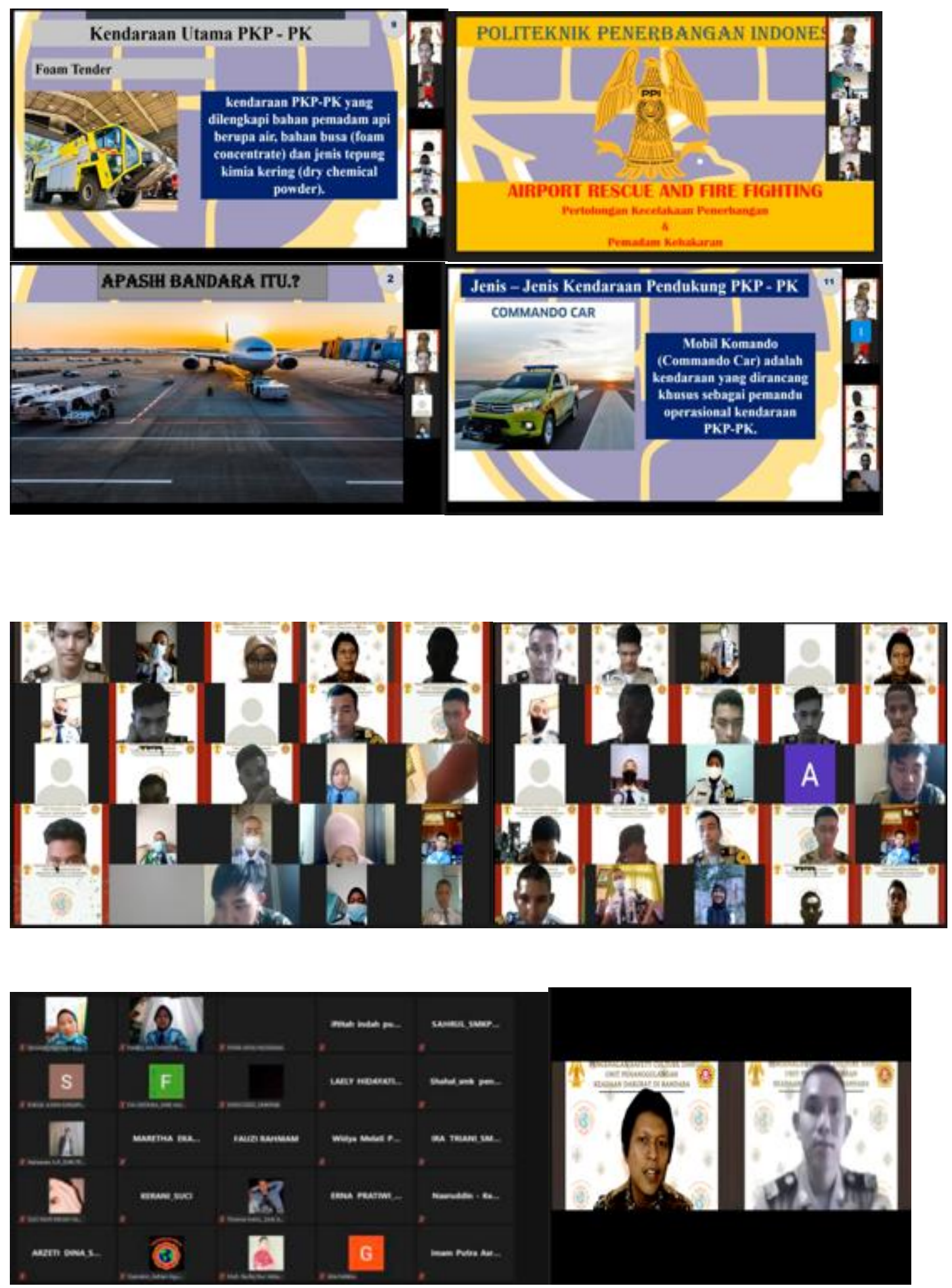
Pengenalan Unit Penanggulangan Keadaan Darurat di Bandara bagi Siswa SMK Penerbangan di Wilayah Lampung dan Sidoarjo

Nawang Kalbuana, Oke Hendra, Pangsa Rizkina Aswia, Dwi Lestary, Kardi Solihin

Volume 1, No. 3, Desember 2021 hal. 232-239

DOI Artikel: 10.46306/jub.v1i3.44

c. Evaluasi Kegiatan PKM oleh Panitia

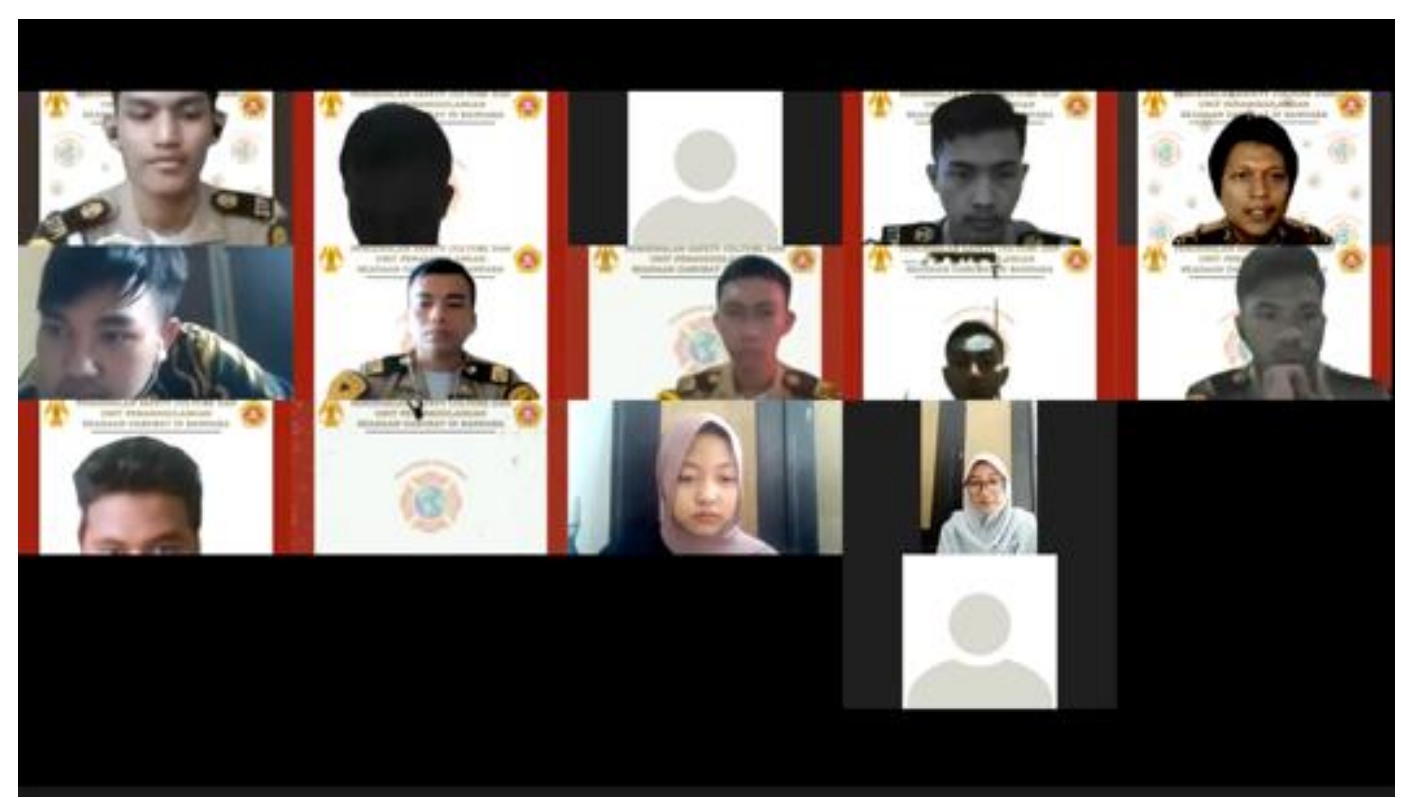

\section{KESIMPULAN DAN SARAN}

Kegiatan webinar mengenai pengenalan unit penanggulangan keadaan darurat di bandara berjalan sesuai dengan jadwal yang ditetapkan. Kegiatan berlangsung dengan baik dan para peserta sangat antusias dengan banyaknya pertanyaan yang diajukan. Peserta yang hadir adalah II3 orang siswa dan siswi SMK Penerbangan di Lampung dan Jawa Timur. Kegiatan webinar secara virtual ini memungkinkan untuk menjangkau peserta yang lebih luas dan beragam.

\section{UCAPAN TERIMA KASIH}

Kegiatan pengabdian kepada masyarakat yang berjudul "Webinar Pengenalan Unit Penanggulangan Keadaan Darurat Di Bandara Bagi Siswa SMK Penerbangan Di Wilayah Lampung Dan Sidoarjo” ini didanai dari DIPA Politeknik Penerbangan Indonesia Curug tahun Anggaran 202I dengan nomor Kontrak 004/SPK/PKM/PPK/8/PPI-202I tanggal 2 Agustus 202I. Dengan terlaksananya kegiatan pengabdian kepada masyarakat ini ungkapan terimakasih penulis sampaikan kepada seluruh pihak yang telah membantu khususnya karang taruna Desa Sedati Gede, Sidoarjo, Jawa Timur dan siswa/siswi SMK Penerbangan yang telah mengikuti kegiatan PKM ini dengan baik serta kepada pihak Pusat Penelitian dan Pengabdian Masyarakat PPI Curug yang telah mewadahi program pengabdian ini sehingga berjalan dengan baik dan lancar. 
Pengenalan Unit Penanggulangan Keadaan Darurat di Bandara bagi Siswa SMK Penerbangan di Wilayah Lampung dan Sidoarjo

Nawang Kalbuana, Oke Hendra, Pangsa Rizkina Aswia, Dwi Lestary, Kardi' Solihin

Volume 1, No. 3, Desember 2021 hal. 232-239

DOI Artikel: 10.46306/jub.v1i3.44

\section{DAFTAR PUSTAKA}

Arnas, Y; Lamtiar, S; Kurniawati, Z; Kurnianto, B; Kalbuana, N. (202I). Factors Affecting Earning Management On Transportation Corporations In Indonesia. International Journal of Economics, Business and Accounting Research (IJEBAR), 5(I), I50-I59. Diambil dari https://jurnal.stieaas.ac.id/index.php/lJEBAR/article/view/2I70/I0I2

Devi, S., Devi, S., Warasniasih, N. M. S., Masdiantini, P. R., \& Musmini, L. S. (2020). The Impact of COVID19 Pandemic on the Financial Performance of Firms on the Indonesia Stock Exchange. Journal of Economics, Business, \& Accountancy Ventura, 23(2), 226-242. https://doi.org// 0.144| 4/jebav.v23i2.23/3

Direktorat Jenderal Perhubungan Udara. (2015). KP 39 Tahun 2015 tentang Standar Teknis dan Operasi Peraturan Keselamatan Sipil - Bagian I 39 (Manual Of Standard CASR - Part I39) Volume I Bandar Udara (Aerodromes). I.

Direktorat Jenderal Perhubungan Udara. (2016). SKEP/ I40/ VI/ 1999 Tentang Persyaratan Dan Prosedur Pengoperasian Kendaraan Di Sisi Udara. In Laboratorium Penelitian dan Pengembangan FARMAKA TROPIS Fakultas Farmasi Universitas Mualawarman, Samarinda, Kalimantan Timur.

Hastomo, W., Karno, A. S. B., Kalbuana, N., Nisfiani, E., \& ETP, L. (202I). Optimasi Deep Learning untuk Prediksi Saham di Masa Pandemi Covid- 19. JEPIN (Jurnal Edukasi dan Penelitian Informatika), 7(2), |33-140. Diambil dari https://jurnal.untan.ac.id/index.php/jepin/article/view/474 I I

Hendriarto, P., Mursidi, A., Kalbuana, N., Aini, N., \& Aslan, A. (202I). Understanding the Implications of Research Skills Development Framework for Indonesian Academic Outcomes Improvement. Jurnal Iqra' : Kajian Ilmu Pendidikan, 6(2), 5I-60. https://doi.org/I0.252I I/JI.V612.I405

Kalbuana, N., \& Kurnianto, B. (20II). Tinjauan Terhadap Motifasi Kaitannya Dengan Produktifitas Kerja Petugas Air Traffic Control Bandar Udara Soekarno-Hatta. Langit Biru: Jurnal Ilmiah Aviasi, 4(9), 916. Diambil dari http://journal.ppicurug.ac.id/index.php/jurnal-ilmiah-aviasi/article/view/307

Kalbuana, N., Kurnianto, B., Saputro, R., Hendra, O., Utami, S., \& Widagdo, R. A. (2020). The Effect of Audit Quality, Managerial ownership, Institutional ownership, and Intellectual Capital toward Earning Management on Transportation Corporations in Indonesia. Solid State Technology, 63(5), 9|76-9/84. Diambil dari http://www.solidstatetechnology.us/index.php/JSST/article/view/8056

Kalbuana, N., Prasetyo, B., Kurnianto, B., Saputro, R., Kurniawati, Z., Utami, S., ... Legok, K. (202I). Liquidity Effect, Profitability Leverage to Company Value: A Case Study Indonesia. European Journal of Molecular \& Clinical Medicine, 7(II), 2800-2822. Diambil dari https://ejmcm.com/article_6290.html

Kementerian Perhubungan Republik Indonesia. (2015). KP I4 Tahun 2015 Standar Teknis dan Operasi Peraturan Keselamatan Penerbangan Sipil Bagian 139 (Manual of Standard CASR Part 139) Volume IV Pelayanan Pertolongan Kecelakaan Penerbangan dan Pemadam Kebakaran (PKP-PK).

Mayanty, S., Rusmana, I. M., \& Nurrahman, A. (202I). Strategi Menjadi Guru Inspiratif di Masa Pandemi (PKM di TK dan SDI AI Kautsar Bintaro School). Jubaedah: Jurnal Pengabdian dan Edukasi Sekolah, I(I), I-I I. Diambil dari http://jubaedah.lppmbinabangsa.id/index.php/home/article/view/I/I2

Menteri Perhubungan Republik Indonesia. (20I5). Peraturan Menteri Perhubungan Republik Indonesia No I27 Tahun 2015 Tentang Program Keamanan Penerbangan Nasional. In Menteri Perhubungan Republik Indonesia.

Nurwati, N., Prastio, P., \& Kalbuana, N. (202I). Influence of Firms Size, Exchange Rate, Profitability and Tax Burden On Transfer Pricing. International Journal of Economics, Business and Accounting Research (IJEBAR), 5(3). https://doi.org// 0.29040/IJEBAR.V5I3.2882

Olivia, S., Gibson, J., \& Nasrudin, R. (2020). Indonesia in the Time of Covid-19. https://doi.org//0.1080/000749/8.2020.179858I, $56(2), \quad$ I43-174. https://doi.org// 0.1080/000749/8.2020.179858।

Pamuraharjo, H. (2020). Airlines sebagai “jembatan udara nasional” NKRI. (I).

Pattiapon, M. L. (Marcy), Kembauw, E. (Esther), Siregar, Z. H. (Zufri), Hardono, J. (Joko), Sarasanty, D. (Diah), Sihombing, A. T. (Alexander), ... Rochmi, A. (Alfi). (202I). Ekonomi Teknik. https://doi.org// 0.0/CSS/ALL.CSS

Prasetyo, B; Utami, S; Abdusshomad, A; Wijaya, M; Kalbuana, N. (202I). Effect Of Company Value, Leverage, And Company Size On Profit Persistence In Jakarta Islamic Index (III) Listed Companies. 
Pengenalan Unit Penanggulangan Keadaan Darurat di Bandara bagi Siswa SMK Penerbangan di Wilayah Lampung dan Sidoarjo

Nawang Kalbuana, Oke Hendra, Pangsa Rizkina Aswia, Dwi Lestary, Kardi Solihin

Volume 1, No. 3, Desember 2021 hal. 232-239

DOI Artikel: 10.46306/jub.v1i3.44

International Journal of Economics, Business and Accounting Research (IJEBAR), 5(I), I28-136. Diambil dari https://jurnal.stie-aas.ac.id/index.php/IJEBAR/article/view/2164/I010

Prasetyo, B., Rohman, T., Solihin, S., Sundoro, S., \& Kalbuana, N. (202I). Sosialisasi Kawasan Keselamatan Operasi Penerbangan (KKOP). Jurnal Pengabdian Kepada Masyarakat (JPKM) Langit Biru, 2, 3I-38. https://doi.org/I0.54I47/JPKM.V2I0I.45I

Presiden Republik Indonesia. (2009). Undang-Undang Republik Indonesia Nomor I Tahun 2009 tentang Penerbangan (hal. 109). hal. 109.

Sihono, Fatkulloh, A., Saputro, Ri., Herwanto, D., Kalbuana, N., \& Kurnianto, B. (202I). Pemantapan Dan Refreshing Materi Electrical \& Electronik Untuk Guru Smk Penerbangan Di Jawa Tengah Dan Sekitarnya. Jubaedah: Jurnal Pengabdian dan Edukasi Sekolah (Indonesian Journal of Community Services and School Education), I(I), 12-19. https://doi.org/I0.46306/JUB.VIII.2

Sparrow, R., Dartanto, T., \& Hartwig, R. (2020). Indonesia Under the New Normal: Challenges and the Way Ahead. https://doi.org//0.1080/000749/8.2020.1854079, 56(3), 269-299. https://doi.org// 0.1080/000749/8.2020.1854079

Today. (202I). Jokowi: Vaksinasi sebagai ikhtiar agar Indonesia bebas pandemi | antaranews.com | LINE TODAY. Diambil 8 September 202I, dari https://today.line.me/id/v2/article/vLVrBE

Vinod, B. (202I). Airline revenue planning and the COVID-I9 pandemic. Journal of Tourism Futures. https://doi.org/I0.I I08/JTF-02-202I-0055

Yohana; Kalbuana, N; Solihin; Yanti, D. R. (2020). The Influence Of Capital Intensity, Firm Size, And Leverage On Tax Avoidance On Companies Registered In Jakarta Islamic Index (Jii) Period 20152019. International Journal of Economics, Business and Accounting Research (IJEBAR), 4(03). Diambil dari http://www.jurnal.stie-aas.ac.id/index.php/JJEBAR/article/view//330/727 